Int. J. Dev. Biol. 52: 823-835 (2008)

doi: $10.1387 / \mathrm{ijdb} .072444 \mathrm{cb}$

\title{
Genes controlling pancreas ontogeny
}

\author{
CLAIRE BONAL and PEDRO L. HERRERA* \\ Department of Genetic Medicine and Development, University of Geneva Medical School, Geneva, Switzerland
}

\begin{abstract}
The pancreas develops from two separate and independent endodermal primordia. The molecular events supporting the early morphological changes that give rise to the formation of the dorsal and ventral pancreatic buds result from coordinated responses to extrinsic and intrinsic signals. The extrinsic signals are involved in processes dictating whether progenitor cells remain as immature or as committed precursors. After specification, the sequential activation of transcription factors determines cell autonomously the commitment and differentiation of these progenitors. During pancreas development, the roles of extrinsic and intrinsic signals are variable, depending on the particular competence of each progenitor cell. We summarize in this review the main events, at the level of gene expression, which are involved in the early stages of pancreas development.
\end{abstract}

KEY WORDS: islet, pancreas, progenitor, endocrine, development, beta cell

The pancreas is an exocrine and endocrine gland of the digestive system (Fig. 1A). The exocrine part represents $95-99 \%$ of the total pancreatic mass. It consists of serous acini of highly polarized cells that produce digestive enzymes (amylase, lipase, phospholipase) as well as pro-enzymes (elastase, procarboxypeptidase, trypsinogen, pepsinogen, deoxyribonuclease, ribonuclease), which are stored in zymogen granules located in their apical pole (Fig. 1CD). Once secreted with water and bicarbonates into the lumen of the acinus, they become activated and forwarded through the ductal network to the duodenum, for the intestinal digestion of nutrients. The ductal tree begins within the acini with very small ducts lined by centroacinar cells, followed by intercalated, intralobular and finally interlobular ducts (Fig. 1CD).

The endocrine pancreas is composed of islets of Langerhans scattered within the exocrine tissue, representing $1-5 \%$ of the pancreatic mass (Fig. 1BC). Adult islets are composed of different cell types characterized by the production of specific hormones: glucagon by $\alpha$-cells, insulin by $\beta$-cells, somatostatin by $\delta$-cells and pancreatic polypeptide by PP-cells. A rare fifth endocrine cell type, the $\varepsilon$-cell, secreting ghrelin, represents about $1 \%$ of the embryonic endocrine pancreas, but disappears after birth. In rodents, islets are composed of a central core of $\beta$-cells, which represent about $80 \%$ of all islet cells, surrounded by a mantle composed of the three other cell types (Fig. 1E). Insulin and glucagon control blood glucose levels, whereas PP and ghrelin are orexigenic hormones and somatostatin regulates the secretion of insulin, glucagon and PP.

\section{Specification of pancreatic fate}

In Mammals, the pancreatic differentiation program is induced in the foregut/midgut junction of the endoderm by factors released from the mesoderm at the $6-10$ somites stage (6-10s) (Fig. 2). Initially, the dorsal endoderm is adjacent to the notochord, before the fusion of the two dorsal aortae at 12-20s (which corresponds to E8.75-9.0 in mice). At this stage, the dorsal pancreatic endoderm is near the dorsal aorta and the dorsal mesenchyme, and the ventral-lateral pancreatic endoderm is adjacent to the septum transversum (i.e. the primordium of the diaphragm) and the cardiogenic mesoderm. The

\footnotetext{
Abbreviations used in this paper: Apc, Adenomatous polyposis coli ; Arx, Aristaless-related homeobox; bHLH, basic helix-loop-helix; Bmp, Bone morphogenic protein; bZIP, basic leucine zipper; CCK, Cholecystokinin; CPA1, Carboxypeptidase A1; Cx, Connexin; Dhh, Desert hedgehog; E, Embryonic day; EGF, Epidermal growth factor; FGF, Fibroblast growth factor; Fox, Forkhead homeobox; Glut2, Glucose transporter 2; Hes1, Hairy enhancer of split; Hex, Haematopoietically expressed homeobox; Hh, Hedgehog; Hnf, Hepatocyte nuclear factor; Isl1, Islet1; Maf, Musculoaponeurotic fibrosarcoma; Ngn3, Neurogenin 3; P, Postnatal day; Pax, Paired homeobox; Pdx1, Pancreatic and duodenal growth factor 1; Prox1, Prospero-related homeobox; Ptch1, Patch1; Ptfla, Pancreas specific transcription factor 1a; s, somites; Shh, Sonic hedgehog; Sox, Sry related hydroxymethylglutaryl homeobox ; Srf, Serum response factor; TGF $\beta$, Transforming growth factor $\beta$; VEGF, Vascular Endothelial Growth Factor.
}

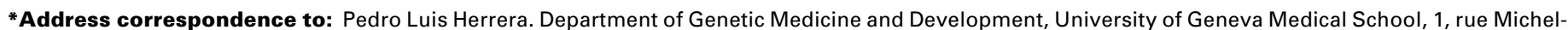
Servet, $\mathrm{CH}-1211$ Geneva 4, Switzerland. e-mail: pedro.herrera@medecine.unige.ch
}

Published online: 19 August 2008

0214-6282/2008/\$35.00

(C) UBC Press

Printed in Spain 

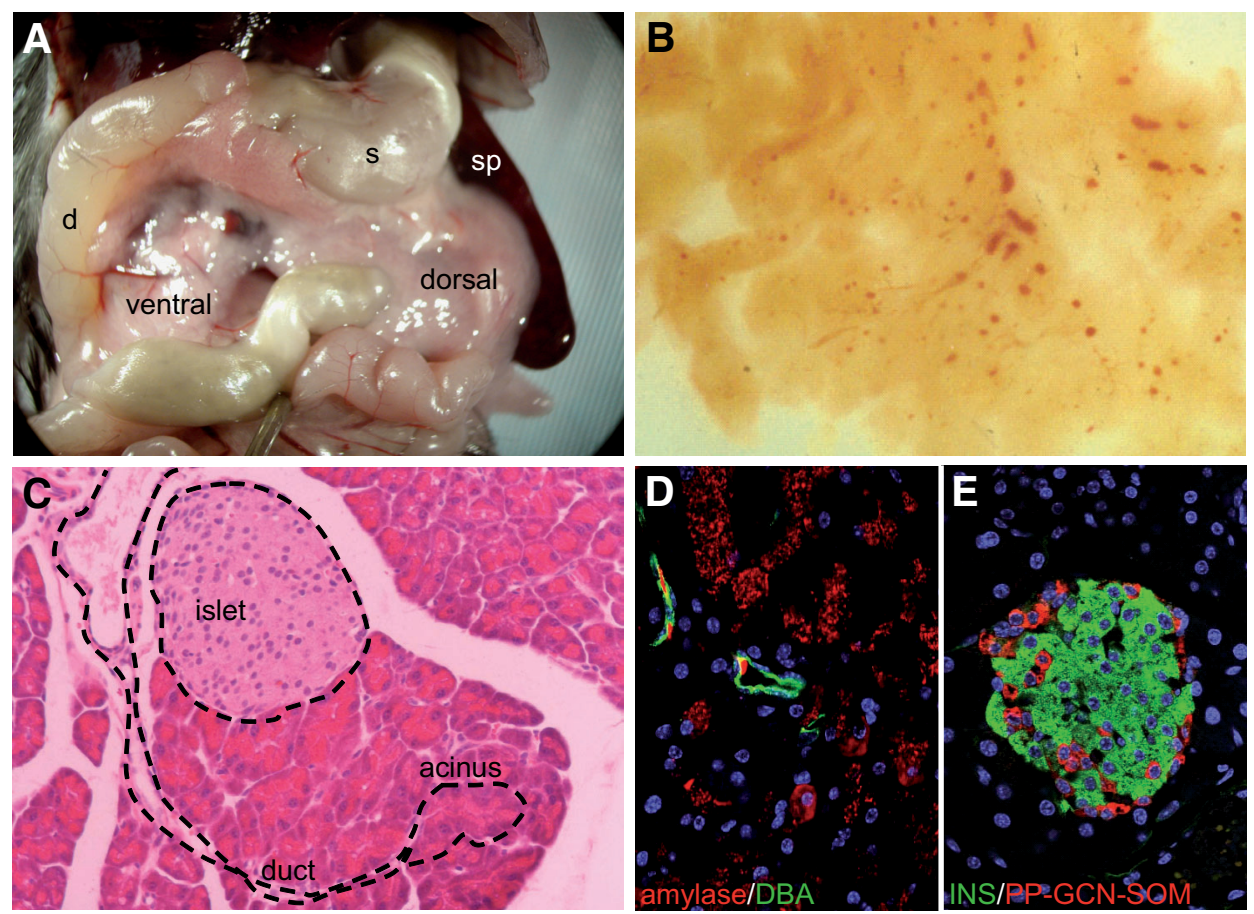

Fig. 1. Macroscopic and microscopic views of the adult mouse pancreas. (A) The duodenal portion of the pancreas ("ventral"), derived from the ventral primordium, is attached to the duodenum (d) and stomach (s), whereas the splenic ("dorsal", derived from the dorsal primordium) pancreas extends towards the spleen (sp). (B) Wholemount adult mouse pancreas perfused with dithizone, which specifically labels $\beta$-cells. The endocrine pancreas is composed of islets of Langerhans (stained in red) scattered among the exocrine tissue. (C) Paraffin section stained with hematoxylin-eosin. Endocrine cells are small and pale, and concentrate in islets. The exocrine gland is composed of secretory units, the serous acini, and excretory ducts: intercalated (small), intralobular and interlobular (large) ducts. Magnification, x100. (D) Immunofluorescence of pancreatic cells. Exocrine cells are acinar cells containing amylase-positive zymogen granules (red immunofluorescence) and ductal cells, stained with the DBA lectin (green immunofluorescence). (E) Islet cells are distributed so as to form a central core of insulin (INS)-expressing cells (green immunofluorescence) surrounded by a mantle of cells expressing either, PP, glucagon (GCN) or somatostatin (SOM) (red immunofluorescence). (D-E) Magnification, $\times 400$

first signs of pancreas organogenesis occur at 22-25s (E9.5). The dorsal mesenchyme condenses and the adjacent endodermal region evaginates to form the dorsal bud. The ventral bud, adjacent to the liver diverticulum appears later, at 30s. Through continuous signals originating from the adjacent mesoderm, pancreatic epithelial cells proliferate and migrate to generate an evagination that branches and invades the surrounding mesenchyme (Fig. 3AB). When the gut rotates clockwise (56$60 \mathrm{~s} ; \mathrm{E} 13.5$ in mice), the ventral bud is brought beside the dorsal bud.

The presumptive region of the pancreas and duodenum is the only part of the primitive gut devoid of Shhexpression. This inhibition, mediated by adjacent mesodermic structures, is required for pancreas organogenesis. Pancreatic and duodenal progenitor cells are characterized by the expression of the transcription factor Pancreatic and duodenal homeobox 1 (Pdx1). The initial induction of $P d x 1$ is triggered by the transcription factor Hnf6. Other factors, such as Hb9 and Isl1 in the dorsal bud, and Hex 1 in the ventral bud, are required for $P d \times 1$ expression. Afterwards, the maintenance of $\Pi \delta \xi 1$ activity depends on mesodermal signals, such as FGFs, which contribute to the induction of Pancreas transcription factor (Ptf1a) in pancreatic progenitors.

\section{Role of the notochord and the cardiac mesoderm}

The repression of $S h h$ in the dorsal pancreatic endoderm is mediated by the adjacent notochord (Kim et al., 1997). This inhibition is permissive for the expression of $P d \times 1$. Hebrok and others determined that TGF $\beta$ ligand (activin $\beta B$ ) and FGF2 are sufficient to inhibit Shh expression in the dorsal endoderm, thus allowing normal pancreas development (Kim et al., 1997). Shh repression and the concomitant pancreatic differentiation were observed in isolated chick endoderm (stage 12) cultured in the presence of high concentrations of activin $\beta B$. A similar effect was obtained when FGF2 concentration was low. On the contrary, disruption of activin $\beta$ B-dependent TGF $\beta$ signaling in mice lacking activin receptors (ActRIIA - - -; ActRI/B - - -), or under extreme FGF2 concentrations (too low and too high), permitted the expression of $S h h$ in the dorsal endoderm, leading to pancreas development disruption (Hebrok et al., 1998). Accordingly, the disruption of $\mathrm{Hh}$ signaling, by treating mice with cyclopamine (an inhibitor of Smoothened) or in Shh-/- and Shh-/,; Ih $h+/$-mutants, promoted the pancreatic differentiation program in non-pancreatic endoderm (rostral stomach and duodenum) (Kim and Melton, 1998).

Similarly, in the anterior leading edge of the embryonic endoderm, Shhrepression defines the presumptive region from which the ventral pancreatic primordium starts to grow at the 2-6s stage (Deutsch etal., 2001). The cardiac mesoderm releases FGFs, which induce Shh expression in the endoderm adjacent to the heart, thus triggering the hepatic development program. The more distal endoderm, on the contrary, is exposed to low FGF levels and does not express $S h h$, therefore adopting the pancreatic program.

\section{Role of vascular structures and the dorsal mesenchyme}

The close vicinity of blood vessels and pancreatic endoderm is essential for pancreatic development. At E8.75-9.0 (12-20s), the two dorsal aortae fuse, separating the notochord from the pancreatic endoderm. The removal of the aorta inhibits pancreas development in Xenopus endoderm; however the pancreas is rescued when the endoderm is cocultured with other non-aortic endothelial cells (Lammert et al., 2001).

The involvement of endothelial cells, whether directly or as vessels containing circulating factors, was also demonstrated using /lk-/-mice, in which the deletion of VEGF receptor inhibits blood vessel formation and thus the dorsal mesenchyme fails to develop (Shalaby et al., 1995, Yoshitomi, 2004). In F/k-/- em- 
bryos, $P d x 1$ is normally expressed in the pancreatic endoderm at 20-25s, yet the dorsal bud does not form and only few $\mathrm{Ptf} 1 \mathrm{a}-$ $\mathrm{Pdx} 1^{+}$cells remain, whereas the pancreatic development of the ventral endoderm is not affected. Interestingly, the E8.5-E9.5 Flk/- dorsal endoderm gives rise to a normal pancreas if cocultured with wild type aorta, thus showing that endothelial cells are supporting cells necessary for dorsal pancreas development.

The dorsal mesenchyme, which is placed between the dorsal aorta and the endoderm, is also involved in promoting the development of the dorsal pancreas, as shown in mice deficient for islet1 (Is/1)or the adhesion molecule $\mathrm{N}$-Cadherin (Cdh2). In these mutants there is no dorsal mesenchyme, and dorsal pancreas development is impaired. Indeed, dorsal pancreas development is modulated by the vascular structures of the dorsal mesenchyme. This was shown after restoration of cardiac development through the cardiac-specific expression of $\mathrm{N}$-Cadherin in the Cdh2-/ background: this is sufficient to reestablish dorsal pancreas development. Similarly, the coculture of aortic cells and dorsal mesenchyme ensures the survival of IsI $1^{+}$cells in the latter (Jacquemin et al., 2006).

The survival signals from the aorta allow the dorsal mesenchyme to secrete FGF10, which in turn promotes dorsal pancreas development (Jacquemin et al., 2006). FGF10 is known to promote the accumulation of $P d \times 1+$ pancreatic progenitor cells. The disruption of FGF signaling leads to pancreatic hypoplasia. Inversely, induction of FGF signaling in animals overexpressing Fgf10, or in vitro with FGF10 treatment, leads to excessive proliferation of progenitor cells and the formation of an oversized pancreas.

Altogether, these results highlight the critical role of the pancreatic mesoderm as source of permissive factors for the development of the pancreas.

\section{Hepatocyte nuclear factor6 (Hnf6)}

The Onecut homeodomain transcription factor Hepatocyte nuclear factor 6 (Hnf6) is expressed from $8 \mathrm{~s}$, shortly prior Pdx1 induction, in the foregut/midgut region of the endoderm, which gives rise to the pancreatic diverticuli. Later, Hnf6is expressed in Pdx1 + progenitors, and becomes restricted to ductal and acinar cells from E18.

Hnf6 is required for adequate $P d x 1$ expression, downstream of $\mathrm{Hb} 9$ and HNF3 $\beta$. Therefore, in Hnf6-/-embryos the induction of $P d x 1$ is delayed, affecting the size of the pancreas from E10.5 to adulthood, without modified proliferation or apoptosis (Jacquemin et al., 2003).

\section{Pancreatic and duodenal growth factor1 (Pdx1)}

The expression of $P d x 1$ starts in the ventral pancreas at E8.5, and about 12 hours later in the dorsal pancreas, as well as in the caudal stomach and proximal duodenum, after Hnf6induction. By E16.5, $P d x 1$ expression diminishes in exocrine lineages and, from E19.0, it is restricted to $\beta$-cells and to $20 \%$ of $\delta$-cells (Fig. 3C).

$P d x 1$ expression is necessary for pancreas development. $P d x 1$ is expressed in all epithelial cells of the developing pancreas and represents the earliest marker of progenitors generating endocrine and exocrine pancreatic cells. The absolute requirement of $\mathrm{Pdx} 1$ during pancreas development was confirmed by genetic loss-of-function experiments. In humans, heterozygous mutations in $P d x 1$ highly predispose to MODY4 diabetes and adult-onset Type II diabetes, and complete absence of $P d x 1$ results in pancreatic aplasia (Stoffers et al., 1997). Similarly, in mice, $P d x 1$ disruption inhibits pancreas development, allowing only a limited growth of the dorsal bud (Jonsson et al., 1994). In addition, $P d x 1$ mutations are frequently associated with pyloric atresia and replacement of duodenal epithelium by Glut2 ${ }^{+}$bile duct-like epithelium. Nevertheless, ectopic $P d x 1$ expression is not sufficient to promote the pancreatic program in non-pancreatic chick endoderm (Grapin-Botton et al., 2001), whereas concomitant expression of $P d x 1$ and Ptf1ais sufficient to convert nonpancreatic endoderm into pancreatic precursors in Xenopus embryos (Afelik et al., 2006).

Recent evidences suggest that the number of $\mathrm{Pdx} 1^{+}$progenitors formed between E8.5 and E12.5 determines the final size of the pancreas (Stanger et al., 2007). The size of the pool of Pdx1+ progenitors depends on the proper commitment and proliferation of early endodermal cells into $\mathrm{Pdx} 1^{+}$cells. The partial ablation of $\mathrm{Pdx} 1^{+}$progenitors or the disruption of Notch, FGF or Wnt/ $\beta$ catenin signaling leads to a very similar phenotype, i.e. a reduced number of $\mathrm{Pdx} 1^{+}$progenitors. This reduction is associated with pancreatic hypoplasia. This suggests that pancreas growth is fixed by the amount of Pdx1+ progenitor cells, and that it follows an intrinsic program (Stanger et al., 2007).

The tight regulation of $P d x 1$ expression allows $P d x 1$ to have multiple roles, depending on its temporal and spatial expression pattern. $P d x 1$ is expressed in the different domains of the caudal

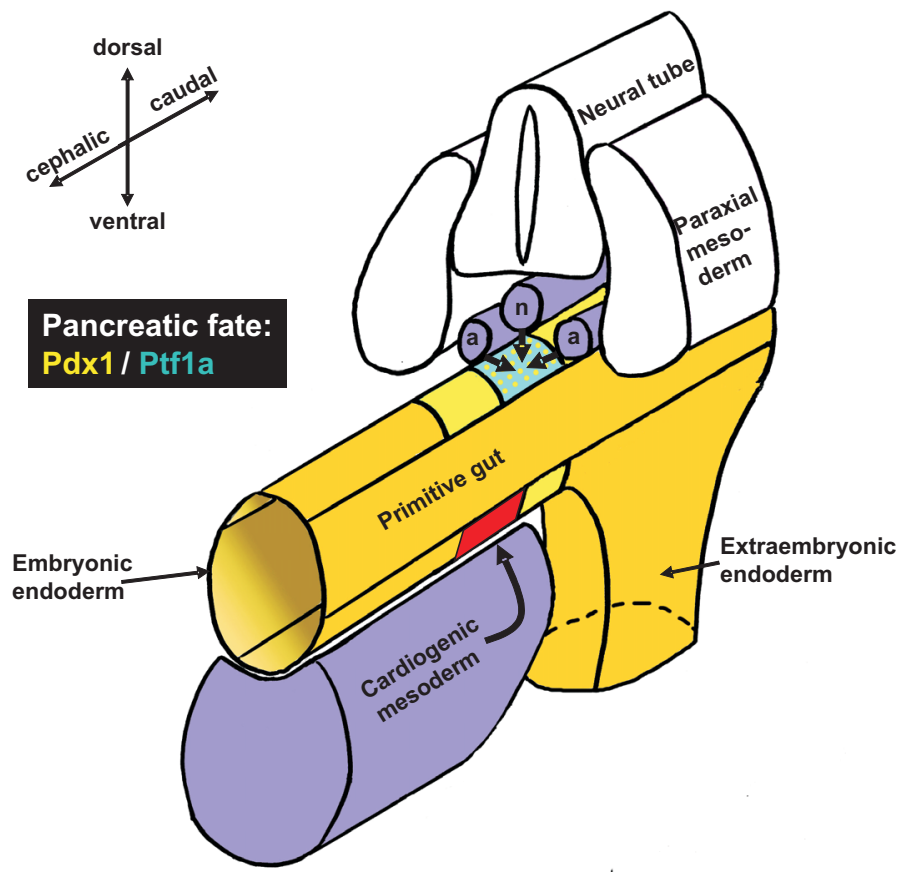

Fig. 2. Schematic view of the foregut/midgut endodermal junction of an E8.5 mouse embryo, oriented along the cephalo-caudal axis. The dorsal endoderm is programmed towards the pancreatic fate in response to mesodermal factors (secreted from the notochord and aortae, in purple); this dorsal endoderm is characterized by the coexpression of Pdx1 (in yellow) and Ptf1a (in blue). Ventrally, the cardiogenic mesoderm defines the presumptive liver (red) in the ventral endoderm. Adjacent to it, at the leading edge of the embryonic endoderm, the ventral pancreatic primordium, which only expresses $P d x 1$, is specified by unknown mechanisms. $n$, notochord; a, aortae. 
stomach, the ventral and dorsal pancreas and the rostral duodenum. The spatial specificity of $P d x 1$ transcription was revealed by deleting the enhancer region I-II-III of $P d x 1$ promoter (Fujitani et al., 2006). The homozygous loss of region I-II-III aborted the ventral budding, while the dorsal bud became hypoplastic, leav- ing the stomach and duodenum unaffected. The hemizygous deletion of the same region only affected the maturation of endocrine progenitors, without any other alteration. Intriguingly, these phenotypes were not complementary.

Until E16.5, the whole pancreatic epithelium expresses $P d x 1$, but its requirement is different throughout development. Using an inducible and reversible transgenic model of $P d x 1$ repression, Holland et al. showed that $P d x 1$ expression is required for early pancreas morphogenesis between E10.5 and E12.5 (Holland et al., 2002). In addition, $\mathrm{Pdx} 1$ is necessary from $E 13.5$ for the genesis of exocrine tissue. Indeed, in absence of $P d \times 1$, Ptf1ainduction is suppressed, which alters the normal expression of acinar markers (Hale etal., 2005). These results demonstrate that $\mathrm{Pdx} 1$ induces Ptf1aactivity during early pancreas morphogenesis, and this is critical for the maturation of the exocrine compartment.

\section{Induction of Pdx1 in the dorsal endoderm}

Two homeobox transcription factors, $\mathrm{Hb} 9$ and Isl 1 , are required for the initial induction of Pdx1 in dorsal pancreatic primordia. Later, persistence of $P d x 1$ expression depends on FGF10 secretion by the dorsal mesoderm, which is ensured by its blood vessels.

The homeobox transcription factor $\mathrm{Hb} 9$ is encoded by the HIxb9 gene. During mouse development, $H / x b 9$ expression starts at E8 in the notochord, the entire dorsal gut endoderm and the ventral endoderm. During pancreas development, $H / x b 9$ expression is transient. Hb9 appears first in the ventral bud at E8, concomitant with $P d x 1$ expression. Afterwards, $H / x b 9$ is expressed in the dorsal bud prior to the dorsal induction of $P d \times 1$. Between E10.5 and E12.5, its expression declines in both buds, but later is expressed in mature $\beta$ cells.

$\mathrm{Hb9}$ is an essential intrinsic signal for dorsal pancreas evagination as well as for initiation of the pancreatic program. The ingalactosidase activity in $\mathrm{Pdx} 1$-cre: $\mathrm{R} 26 \mathrm{R}$ (Herrera, 2000, Soriano, 1999) pancreas reveals the $\mathrm{Pd} \mathrm{d} 1$ expression domain in the ventral (vp) and dorsal (dp) primordia, as well as in the caudal stomach (s) and the proximal duodenum (d). Calibration bar, $1 \mathrm{~mm}$. (B) Hematoxylin-eosin stained paraffin sections. From E10.5, the pancreatic epithelium grows by branching morphogenesis, thus forming the ductal tree, from which the endocrine cells originate and delaminate to eventually form the islets within the interstitia between growing ducts. Acinar cells differentiate at the tips of the branches. Calibration bar, $100 \mu \mathrm{m}$. (C) Immunodetection of $P d x 1$. From E10.5, $\mathrm{Pdx} 1$ is widely expressed throughout the pancreatic epithelium but is progressively restricted to $\beta$-cells after birth. From E15.5, Pdx $1^{\text {High }}$ cells are differentiating $\beta$-cells. Calibration bar, $50 \mu \mathrm{m}$. (D) Schematic view of differentiating cells of the endocrine (green) and acinar (pink) lineages, adjacent to the primitive or mature ductal cells (yellow). Calibration bar, $100 \mu \mathrm{m}$. 
activation of $H / x b 9$ affects selectively the emergence of the dorsal bud and the dorsal activation of $P d \times 1$, such that the ventral bud develops normally, although with altered islet architecture. In addition, maturation of $\beta$-cells is impaired: glucose transporter 2 (Glut2) is absent (Harrison et al., 1999).

The requirement of $\mathrm{Hb} 9$ during pancreas development is transient. This was shown by ectopically expressing HIxb9 in $P d x 1+$ cells: at E15.5, the mutant pancreas was small and poorly branched because the pancreatic epithelium and adjacent mesenchyme adopted an intestinal-like differentiation program (Li and Edlund, 2001). This suggests a non-cell autonomous effect for $H / x b 9$ on the surrounding mesoderm.

The second factor determinant for dorsal $P d x 1$ induction is the LIM homeobox transcription factor Is I1. It was initially identified as a transcription factor binding the insulin gene enhancer region. During pancreas development, it is expressed from 15-16s (E9.0) in the dorsal pancreatic epithelium and in the gut mesenchyme (Ahlgren et al., 1997). By 20-25s, /s/1 expression becomes restricted to endocrine and mesenchymal cells of the dorsal bud.

Isl1 plays a pancreas development-promoting role, both as an extrinsic factor produced by the dorsal mesenchyme, and intrinsically expressed in pancreatic progenitors. The inactivation of /s/1 leads to the selective depletion of the dorsal mesenchyme, associated with altered $P d x 1$ expression in the dorsal epithelium (Ahlgren et al., 1997). Since /s/1-/-embryos die at E9.5, pancreas differentiation was further analyzed in cultured explants. In absence of $/ s / 1$, no endocrine cells differentiate. In addition, exocrine cells appear only in the ventral bud. The depletion of acinar cells in the dorsal primordium was due to impaired development of dorsal mesenchyme in a non-cell autonomous effect, because /s/1-/-dorsal buds cocultured with wild type dorsal mesoderm only develop acinar cells, but not endocrine cells (Ahlgren etal., 1997). This suggests that $/ s / 1$ expression in the dorsal mesenchyme is required for its maintenance and, indirectly, for exocrine pancreas differentiation, whereas /s/1 expressed in pancreatic progenitors is necessary for endocrine pancreas differentiation.

\section{Induction of $\mathrm{Pdx} 1$ in the ventral endoderm}

The homeobox transcription factor Hex, of the Antennapedia/ Fushi Tarazu class, is expressed from E7.0 in the ventral-lateral foregut, which gives rise to the ventral pancreas and liver.

Hex inactivation inhibits the expansion and the anterior displacement of the ventral-lateral embryonic endoderm, due to a deficient proliferation of endodermal cells (Bort et al., 2004). In absence of this morphogenetic movement, endodermal cells accumulate near the cardiac mesoderm, and thus begin the hepatic differentiation program. For this reason, the presumptive pancreatic endoderm does not form and there is no ventral induction of $P d x 1$ or Ptf1a (Bort et al., 2004). Interestingly, however, the ventral-lateral endoderm isolated from E8 Hex-/embryos fully commits towards pancreatic fates in vitro (Bort et al., 2004). These results suggest that $\mathrm{Hex}$ is not required for the specification of the ventral pancreatic fate, but for the proper location of pancreatic progenitors in the leading-edge of the ventral embryonic endoderm, which can then escape the influence of mesenchymal inhibitors.

\section{Pancreas specific transcription factor1a (Ptf1a, p48)}

The basic helix-loop-helix Pancreas specific transcription fac- tor1 (Ptf1) is composed of 3 different subunits: p75, for nuclear translocation, and two heterodimeric bHLH DNA-binding subunits, p64 and Ptf1a (also called p48). Ptf1a mRNA is detected from E9.5 (the protein from E10) in the whole primordia. From E16, its expression becomes restricted to acinar cells.

Genetic cell tracing analyses confirmed that Ptf1a is a bona fide pancreatic marker, even better than $\mathrm{Pdx} 1$, which is expressed earlier but not exclusively in the pancreas. The role of Ptf1a in pancreatic specification was shown using a Ptfla promoter driving the expression of $P d x 1$ in a $P d x 1$ knock out background: pancreas development was almost normal, with partial restoration of exocrine, ductal and endocrine cells (Kawaguchi et al., 2002). Ptf1aexpression is induced in the dorsal pancreatic bud by $P d x 1$. The ventral induction of Ptf1a remains unexplained.

Interestingly, the inactivation of Ptf1a selectively affects the exocrine compartment. The exocrine progenitors are reprogrammed into duodenal fates as shown by cell tracing analysis (Kawaguchi et al., 2002). Directly or indirectly, Ptf1a inactivation also affects the endocrine pancreas, leading to the relocation of the scarce endocrine cells within the spleen. These results suggest that Ptf1a is somehow involved in both endocrine and exocrine lineages.

\section{Maintenance of uncommitted pancreatic progenitors}

The initial pancreatic diverticuli are made of undifferentiated epithelial cells that proliferate and branch, invading the surrounding mesoderm. Cell specification and commitment occur through a sequential activation of genes (Fig. 4). The initial commitment into specified progenitors, whether endocrine or exocrine, is repressed by active Notch signaling and Sox9 activity, which promote progenitor expansion at the expense of their differentiation. Later, commitment towards endocrine or exocrine fates is modulated by active TGF $\beta$ signaling and by Prox 1 , which prevent exocrine commitment and favor the endocrine fate.

\section{Notch signaling}

The Notch pathway mediates the control of progenitor selfrenewal. In the pancreas, Notch signaling controls the maintenance of progenitors in an uncommitted state, ensuring the expansion of $\mathrm{Pdx} 1^{+}$progenitors up to E12.5. In this way, Notch signaling influences the final size of the pancreas (Apelqvist et al., 1999). Therefore, disruption of Notch signaling triggers the premature differentiation of pancreatic progenitors (Apelqvist et al., 1999).

\section{Sox9}

Members of the Sry related "high mobility group" (HMG) box (Sox) transcription factor family participate in the maintenance of undifferentiated progenitor cells in different organs, such as the central nervous system or the intestinal epithelium.

Among the Sox factors expressed in the developing pancreas, Sox9 is present in $P d \times 1$-expressing progenitors from E9.5 (Seymour et al., 2007). By E15.5, Sox9 expression becomes restricted to a subset of Notch-responsive and mitotically active $\mathrm{Pdx} 1^{+}$cells (Seymour et al., 2007). During progenitor cell specification, Sox9 expression mostly disappears, but persists in the adult, in centroacinar cells and in few ductal cells (Seymour et al., 2007). 
The conditional inactivation of Sox9 in pancreatic $\mathrm{Pdx} 1^{+}$progenitors impairs organ growth from E11.5 (Seymour et al., 2007). At E18.5, the hypoplastic mutant pancreas is depleted of endocrine cells, whereas the small exocrine compartment presents defective differentiation. In absence of Sox9, the pool of progenitors is reduced due to increased apoptosis, decreased proliferation and premature differentiation (Seymour et al., 2007). Inversely, Fgf10 overexpression in $P d x 1$-expressing progenitors induces the expansion of undifferentiated cells, which bear Notch receptors and express Sox9 (Seymour et al., 2007).

\section{Transforming growth factor $\beta$ (TGF $\beta$ ) signaling}

The developing and adult pancreas expresses TGF $\beta$ signaling ligands, like TGF 1 , activins and bone morphogenetic proteins (Bmps). They are produced by epithelial cells and affect cell commitment and differentiation in paracrine ways.

TGF $\beta$ signaling activity appears to be critical for pancreas

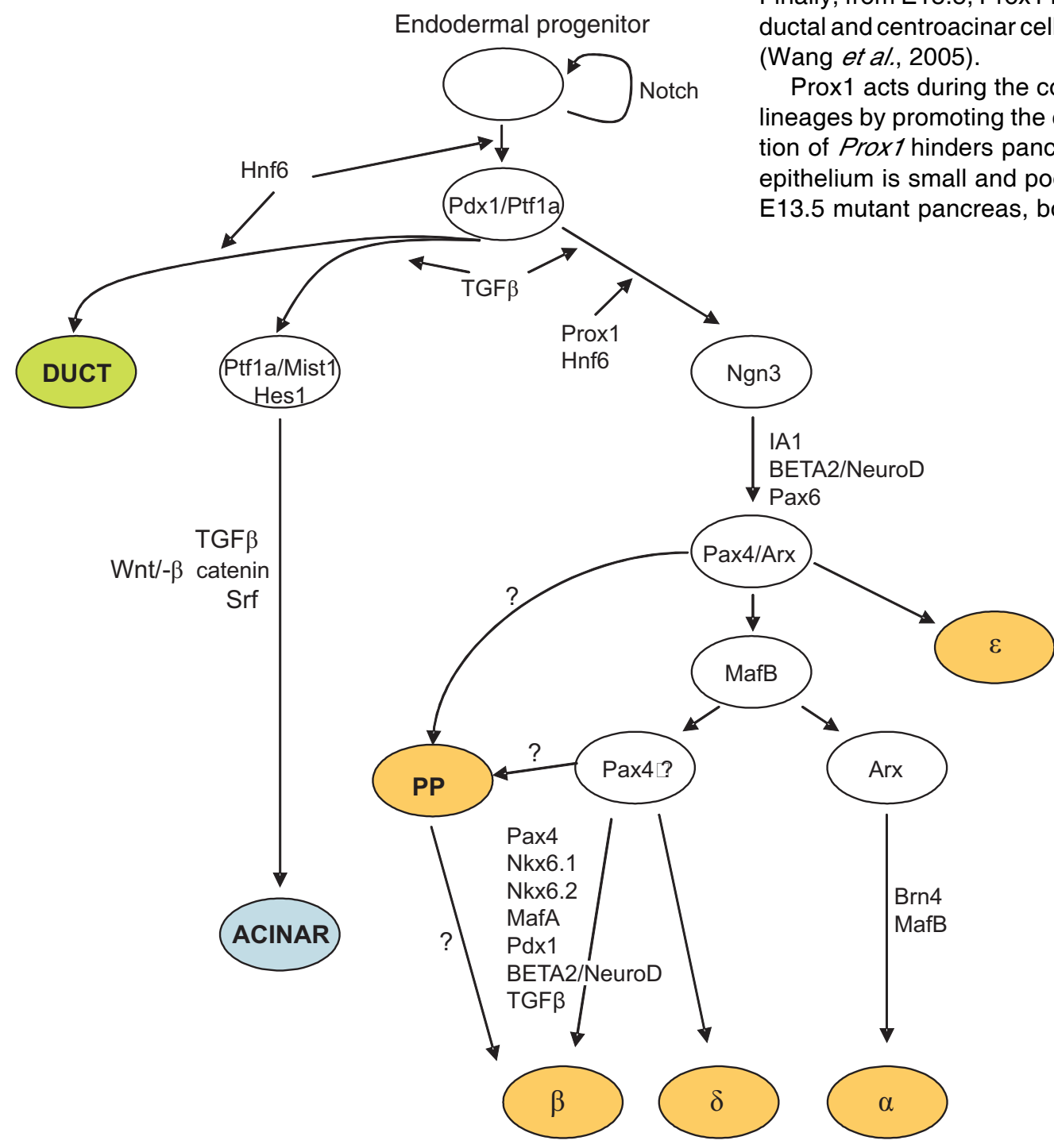

Fig. 4. Simplified model of transcription factor requirement during the specification of endocrine and exocrine pancreas. growth and differentiation. The expression of $B m p 4$ in $\mathrm{Pdx}^{+}$ expressing progenitors leads to pancreas agenesis. Inversely, Smad7overexpression in $\mathrm{Pdx} 1^{+}$progenitors impairs growth and differentiation of endocrine and acinar cells.

In addition to its role in the maintenance of unspecified pancreatic progenitors, TGF $\beta$ signaling contributes to determine the ratio of the three epithelial pancreatic cell types, favoring the endocrine lineage without affecting the ductal cell mass (Sanvito et al., 1994). The disruption of TGF $\beta$ signaling in Bmp11-/-or Smad2+1 -mice, results in altered proportions of acinar and endocrine cells (Harmon et al., 2004).

\section{Prospero-related homeobox transcription factor1 (Prox1)}

Prox 1 is first expressed at E7.5 in endodermal cells. At E8.5 (10-12s), it is expressed in the presumptive hepatic endoderm and, at 15-18s, in the dorsal pancreas. Prior to the outgrowth of the pancreatic buds, at E9.5, Prox 1 is expressed in early Pdx1+ cells. By $\mathrm{E} 13.5$, it is expressed in $\mathrm{Ngn}^{+}$endocrine progenitors. Finally, from E15.5, Prox1 is specifically expressed in endocrine, ductal and centroacinar cells, while it is excluded from acinar cells Wang et al., 2005).

Prox1 acts during the commitment of the different pancreatic

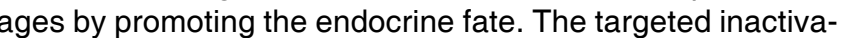
epithelium is small and poorly branched (Wang et al., 2005). In endocrine $\mathrm{Ngn}^{+}$progenitors and duced (Wang et al., 2005).

\section{Specification of endocrine progenitors}

Very early in pancreatic primordia, the first wave of endocrine cell generation, so-called "first transition", is characterized by the appearance of glucagon- (E9.5), pancreatic polypeptide family- (E10.5), insulin- (E10.5) and ghrelin-producing cells (E10.5) within the primitive ductal epithelium (Fig. 3D). These early hormone-expressing cells are different from other endocrine cells appearing during the "secondary transition" (E13.5-E15.5), as they probably do not contribute to the endocrine cell pool of mature pancreas. Originating from specific progenitors expressing $\mathrm{Ngn3}$, the endocrine cells at the "secondary transition" differentiate, while migrating and grouping to form islet-like clusters at E16, and finally islets from E18-19, during the "third transition". The specification into the mature endocrine cell types relies on the activity of early factors involved in the segregation of the endocrine lineages (IA1, Arx, Pax4, Nkx2.2, 
Nkx6.1, MafB), and of late factors involved in the maturation of committed endocrine cells (Pax6, Isl1, Pdx1, Brn4, Hb9, MafA).

\section{Hepatocyte nuclear factor6 (Hnf6)}

Hnf6 activates $P d x 1$ expression and is involved in endocrine commitment/differentiation, but is absent in mature endocrine cells. In Hnf6-/-animals there is a drastic downregulation of $\mathrm{Ngn3}$ expression, which therefore affects the differentiation of all endocrine cell types (Jacquemin et al., 2000). Mice are viable, but intolerant to glucose. Endocrine cells appear scattered and become arranged in islets only 2-3 weeks after birth, with altered architecture and impaired $\beta$-cell differentiation (Jacquemin et al., 2000).

\section{Neurogenin3 (Ngn3)}

The bHLH transcription factor $\mathrm{Ngn} 3$ is expressed from E8.5 in the pancreatic endoderm, peaking at E15.5 and diminishing at birth (Apelqvist et al., 1999). It is transiently co-expressed with NkX6.1 and BETA2/NeuroD1 prior to hormone production. Cell tracing studies demonstrated that while all pancreatic endocrine cell derive from progenitors having expressed Ngn3during development, the early glucagon- and insulin-expressing cells formed before the "secondary transition" originate independently of $\mathrm{Ngn3}$ expression. Whether Ngn3 expression persists after birth is controversial. Two reports, using in situ hybridization and immunohistochemistry, failed to detect $\mathrm{Ngn3}$ expression in the adult pancreas (Jensen et al., 2000, Schwitzgebel et al., 2000). On another hand, cell tracing analyses designed to tag Ngn3+ cells only in the adult, revealed the presence of few Ngn3-expressing cells, devoid of hormone expression, in some islets. Their maintenance in the adult suggests that they might contribute to islet cell renewal.

Inactivation of $\mathrm{Ngn3}$ induces islet agenesis (Gradwohl et al., 2000). Expression of islet-specific transcription factors $(/ s / 1$, Pax4, Pax6 and BETA2/NeuroD1) is suppressed in Ngn3null pancreas, suggesting that $\mathrm{Ngn} 3$ acts upstream of these factors. The ectopic expression of $\mathrm{Ngn} 3$ in the presumptive endodermal regions of stomach and duodenum is sufficient to initiate the endocrine program, with the differentiation of almost only $\alpha$-cells (Apelqvist et al., 1999).

Ngn3 expression is repressed by active Notch signaling (Apelqvist etal., 1999). Thus, Notch disruption leads to premature expression of $\mathrm{Ngn3}$ and accelerated endocrine differentiation (Apelqvist et al., 1999). In addition, Ngn3 expression is also modulated by Hnf6 (Jacquemin et al., 2000).

The mechanisms involved in endocrine specification downstream of Ngn3are still to be defined. Recently, Johansson et al. studied whether all $\mathrm{Ngn}^{+}$cells are alike at different developmental stages, i.e. whether their competence over time is maintained or not (Johansson et al., 2007). Using a system to precisely activate $\mathrm{Ngn} 3$ in $P d \times 1$-expressing progenitors at different timepoints, they showed that from E11.5, the induced Ngn3 activity favored the differentiation towards $\beta$ - and PP- cell phenotypes, while $\mathrm{Ngn} 3$ induction from E14.5 promoted $\delta$-cell differentiation (Johansson et al., 2007).

\section{IA1}

The Insulinoma-associated 1 (Insm1) gene, which encodes the zinc-finger transcription factor IA1, is a direct target of $\mathrm{Ngn3}$
: IA1 is absent in the Ngn3-null pancreas, but is unaffected in mutants for BETA2/NeuroD1, Arx, Pax4 and Pax6 (Mellitzer et al., 2006). Ectopic Ngn3 expression in pancreatic ductal cells induces Insm1 prior to Pax4, BETA2/NeuroD1 and Nkx2.2 (Mellitzer et al., 2006). During pancreatic development, IA1 appears in scattered cells from E10.5 and is expressed in most of $\mathrm{Ngn}^{+}$cells at E15.5 (Mellitzer et al., 2006). In developing and mature pancreas, Insm1 expression is excluded from the exocrine lineage (Mellitzer et al., 2006, Gierl, 2006 \#2439). Whether Insm1 expression persists in postnatal islet cells is controversial (Mellitzer et al., 2006, Gierl, 2006 \#2439).

Insm 1 expression by it-self is not sufficient to drive the endocrine program, but it promotes the effect of Ngn3 (Mellitzer et al., 2006). The few endocrine cells formed in insm-/-embryos have a deficient maturation at E15.5. In $\beta$-cells, the expression of $N k \times 6.1$ and Proconvertase $1 / 3$ is downregulated, while MafA is absent. In $\alpha$-cells, the activity of MafB, Arx and Pax 6 is also downregulated (Gierl et al., 2006).

\section{NKX transcription factors}

The Nkx protein family consists of a large group of homeodomain transcription factors. In the developing pancreas, three Nkxs, 2.2, 6.1 and 6.2 are regulators of endocrine pancreas development.

\section{Nkx2.2}

From E9.5, Nkx2.2expression is wide in the pancreatic region. After E12.5, its expression becomes restricted to a subset of $\mathrm{Ngn}^{+}$cells (Sussel et al., 1998) and persists in the adult, in differentiated $\alpha-, \beta$ - and PP-expressing cells.

Nkx2.2 is required for $\beta$-, $\alpha$ - and PP-cell commitment and differentiation. In Nkx2.2-/-newborns, $\beta$-cells are absent and $\alpha$ and PP-cells are reduced, while $\varepsilon$-cell numbers increase (Sussel et al., 1998). In mutant islets, the majority of endocrine cells have impaired differentiation (Sussel et al., 1998).

$N k \times 2.2$ and $N k \times 6.1$ (see below) co-express in $\mathrm{Ngn}^{+}$progenitors and in mature $\beta$-cells, which suggests that they may cooperate together during $\beta$-cell differentiation. Indeed, the epistatic activity of $N k \times 2.2$ on $N k \times 6.1$ was demonstrated by comparing single and double knock-out phenotypes (Sander et al., 2000).

\section{Nkx6. 1 and Nkx6.2}

Their high degree of homology suggests that there is functional redundancy between 6.1 and 6.2. However, Nkx6.1 and Nkx6.2 expression domains are distinct. Nkx6.1 is first detected in E10.5 pancreatic epithelium, only in $\mathrm{Ngn}^{+}$progenitors and then in adult $\beta$-cells (Sander et al., 2000). Nkx6.1 expression is suppressed in $P d \times 1-/-$ pancreata and, inversely, it is ectopically induced after $P d x 1$ overexpression. Early insulin- and glucagon-positive cells do not express $N k \times 6.1$.

Nkx6.2 is expressed like $N k \times 6$. 1through the pancreatic epithelium from E10.5. By E15.5, it is expressed in $\alpha$ - and acinar cells, and is excluded from $\mathrm{Ngn} 3+$ cells, but around birth its expression disappears (Sander et al., 2000).

The disruption of $N k \times 6.1$ reveals its involvement in $\beta$-cell proliferation, specifically after E12.5, leading to a decreased $\beta$ cell mass (Sander et al., 2000). In absence of Nkx6.1, Nkx6.2expressing cells are more numerous, while keeping a normal spatial and temporal expression pattern, which suggests a potential functional compensation (Henseleit et al., 2005). In absence 
of $N k x 6.2$, the pancreas develops normally; however, the coinactivation of $N k \times 6.2$ and $N k \times 6.1$ reveals its requirement for the normal proliferation of $\beta$ - and $\alpha$-cells. In Nkx6.1-\%; Nkx6.2\%pancreata, the number of $\mathrm{Ngn}^{+}$progenitors is conserved, as well as that of $\delta$ - and PP-cells, but $\beta$ - and $\alpha$-cell numbers are reduced (Henseleit et al., 2005).

\section{Pax4 and Arx}

In the developing mouse pancreas, both Pax4 and $A r x$ are expressed from E9.5 (Collombat et al., 2003, Sosa-Pineda et al., 1997). Even if $A r x$ and Pax4overlap at E13.5 in Ngn3-expressing progenitors, they become mutually exclusive from E18.5. Pax4 is restricted to progenitors differentiating into $\beta$-and $\delta$-cells, whereas $A r x$ is expressed in progenitors differentiating into $\alpha$ - and $\varepsilon$-cells (Collombat et al., 2003). Postnatally, Pax4 is not expressed, or at very low levels in $\beta$-cells and $A r x$ expression persists in mature $\alpha$-cells.

Pax4 and Arx act downstream of $\mathrm{Ngn} 3$ within a regulatory network that determines the final proportions of the different endocrine cell types. Pax4 and Arx have opposite roles. According to their expression pattern, $\mathrm{Pax} 4$ promotes the commitment of $\mathrm{Ngn}^{+}$progenitors into $\beta$ - and $\delta$-lineages, whereas Arx promotes $\alpha$ - and $\varepsilon$-lineages. Pax4-/-islets are composed of $\alpha$ - and $\varepsilon$-cells, and lack $\beta$ - and $\delta$-cells (Sosa-Pineda et al., 1997). Similarly, $A r x$ $-/$-islets are composed of $\beta$ - and $\delta$-cells exclusively (Collombat $e t$ al., 2003).

The expression of Pax4 is directly promoted by Ngn3 and Hnf $1 \alpha$, and is repressed by Arx (Collombat et al., 2003). Pax4 and Arx inhibit each other directly (Collombat et al., 2003). In Pax4-/ - pups, Arx expression is upregulated, while in $A r x-/-$ newborns Pax4 is upregulated. Interestingly, the double inactivation of Pax4 and $A r x$ results in a normal number of endocrine cells, which produce somatostatin, and when pups start suckling, these cells begin to co-express PP (Collombat et al., 2005).

\section{Musculo-aponeurotic fibrosarcomaB (MafB)}

MafA and MafB are members of Musculo-aponeurotic fibrosarcoma family of leucine zipper (ZIP) transcription factors. They activate Insulin and glucagon transcription. Both Mafs are involved in the maturation of committed endocrine cells: MafA in $\beta$ cell differentiation and MafB in the lineages of both $\alpha$ - and $\beta$-cells (Nishimura et al., 2006).

MafBis selectively expressed in mature $\alpha$-cells, independently of Pax4 and Pax6 (Artner et al., 2006), but its expression pattern during development reveals a role for MafB in the lineages of both $\alpha$ - and $\beta$-cells (Nishimura et al., 2006). During pancreas development, the first insulin-cells express MafBand then switch to MafA instead, after $N k \times 6.1$ and $P d \times 1$ induction, like mature $\beta$-cells.

\section{Maintenance of islet cell identity}

Differentiated endocrine cells maintain their characteristics thanks to the permanent expression of maturation genes. The transcription factor Pax6 is necessary for the expansion and maturation of all endocrine cells, and for islet organization. TGF $\beta$ signaling controls the number and differentiation of $\beta$-cells, by promoting their differentiation. Three transcription factors, MafA, $\mathrm{Pdx} 1$ and BETA2/NeuroD, participate in the transcription of Insulin and together they represent a "molecular signature" of $\beta$ - cell identity. Concerning $\alpha$-cell identity, the transcription factor Brn4 is determinant for glucagon expression.

\section{Paired homeobox transcription factor6 (Pax6)}

Pax6 is expressed in scattered cells from E9.0 and becomes restricted to islet cells after birth. With a genetic cell tracing analysis it was shown that Pax6 is expressed in the progenitors of all islet cell types.

Pax6 is involved in the expansion of all islet endocrine cell types. Its inactivation reduces the number of endocrine cells, in particular that of $\alpha$-cells. The few endocrine cells that differentiate, are clustered into disorganized islets, and produce quantitatively less hormones. The late requirement of Pax6 in endocrine cell maturation was demonstrated by its conditional inactivation in Pax6-expressing cells only (Ashery-Padan et al., 2004). In Pax4/; Pax6-/- double mutants, the adult pancreas is completely devoid of endocrine cells, a phenotype which mimics the combined phenotypes of each simple mutant. Thus, cells expressing only Pax6 differentiate into $\alpha$-cells and cells co-expressing Pax 4 and Pax6 differentiate into $\beta$-, $\delta$-, $\varepsilon$ - and PP-cells (Collombat et al., 2003).

\section{Maintenance of $\beta$-cell identity}

\section{TGF $\beta$ signaling}

TGF $\beta$ modulates the proportions of acinar and endocrine cells, and promotes the differentiation of $\beta$-cells (Harmon et al., 2004).

Disruption of TGF $\beta$ signaling results in the accelerated formation and accumulation of $\mathrm{Ngn}^{+}$progenitors, with impaired $\beta$-cell differentiation (Harmon et al., 2004). In these conditions, the islet mass is slightly increased, and composed of defective $\beta$-cells. In Gdf11-/- pancreata, $\beta$-cells are immature: they express $N k x 6.1$ but not Insulin(Harmon et al., 2004). Similarly, the conditional expression of the inhibitory Smad7in adult $\beta$-cells impairs the expression of the $\beta$-cell markers, Insulin, MafA, Menin and its target gene, p27kip1, associated with diabetes onset (Smart et al., 2006).

Downstream of TGF $\beta$ signaling, the transcription factor Klf11 activates the glucose-induced transcription of Insulin. Mutations of this factor impair its transcriptional activity, and are associated with human early-onset type II diabetes (Neve et al., 2005).

\section{MafA}

MafA is restricted to $\beta$-cells in adult pancreas. MafA is an activator of Insulin, binding to the enhancer elements RIPE3b/ $\mathrm{C} 1-\mathrm{A} 2$ of the insulin promoter, in response to glucose. The other transcription factors interacting with the conserved insulin enhancer elements are $\mathrm{Pdx} 1$, which binds the $\mathrm{A} 3$ box, and BETA2/NeuroD1, which binds the E1 element.

MafA is involved in the maintenance of $\beta$-cell identity. MafA inactivation does not alter $\beta$-cell development, but in adult knock-out mice, the $\beta$-cell mass becomes dysfunctional, such that there is diabetes onset 12 weeks after birth. The expression of $\beta$-cell markers such as Insulin1, Insulin2, $P d x 1$, BETA2/ NeuroD1 and Glut2 is downregulated and the $\beta$-cell mass decreases due to $\beta$-cell apoptosis (Zhang et al., 2005). This late phenotype suggests that MafA is not necessary for embryonic 
pancreas development but is required for the maintenance of a functional $\beta$-cell mass.

In the program of endocrine differentiation, MafA is located downstream of Pax4 and Pax6 (Sosa-Pineda, 2004). In turn, MafA contributes to activate $P d x 1$ expression and thus to maintain the mature $\beta$-cells.

\section{BETA2/NeuroD}

The bHLHL transcription factor BETA2/NeuroD is a potent transcriptional activator of Insulin, by binding to the $\mathrm{E} 1$ box of the RIP3b/C1-A2 enhancer of the insulin promoter. BETA2/ NeuroDis expressed from E9.5 in scattered cells of the pancreatic epithelium and from E14.5, in Ngn3-expressing cells. After birth, its expression is restricted to $\beta$-cells.

BETA2/NeuroD is a downstream target of $\mathrm{Ngn} 3$, involved in the formation and maturation of the $\beta$-cell mass. BETA2/NeuroD$/$ - pancreata have impaired islet morphogenesis, with a reduction in the number of endocrine cells, especially $\beta$-cells, as a consequence of increased apoptosis from E17 (Naya et al., 1997).

\section{$P d \times 1$}

The bHLH transcription factor $\mathrm{Pdx} 1$ is also one of the activators of Insulin expression, binding to the A3 box of the RIP3b/ C1-A2 enhancer of the insulin promoter. $P d x 1$ expression is almost restricted to $\beta$-cells from E19.0, and is necessary for the transcriptional regulation of many $\beta$-cell markers, such as Glut2 and Glucokinase (Serup et al., 1995).

The conditional repression of $P d x 1$ inhibits insulin expression and induces diabetes 14 days later (Holland et al., 2005). Following derepression of $P d \times 1$, normoglycemia is restored in 28 days. During this period, a regenerative program is induced, with compensatory neogenesis of $\beta$-cells and induction of genes activated during regeneration such as Regenerating islet-derived (Reg) genes (Holland et al., 2005).

\section{Hedgehog signaling}

$\mathrm{Hh}$ signaling is necessary to maintain $\beta$-cell identity in vitro, whereas during development, it inhibits the pancreatic specification of the endoderm (Thomas et al., 2000). Primary isolated $\beta$-cells and INS1 cells both express Hedgehogligands and the receptor Ptc1 (Thomas et al., 2000). Hedgehog signals activate $P d x 1$ transcription, which in turn stimulates Insulin expression (Thomas et al., 2001). Inversely, cyclopamine treatment (Smoothen inhibitor) inhibits $P d \times 1$ and Insulin transcription (Thomas et al., 2001).

\section{Maintenance of $\alpha$-cell identity}

\section{Brn4}

The POU-homeobox transcription factor 4 brain4/POU3F4 (Brn4) is expressed from E10.5 in early glucagon+ cells. Some of Brn4+ cells coexpress Pax6and /s/1 (Heller et al., 2004). At $\mathrm{E} 14.5, B r n 4$ expression is restricted to $\alpha$-cells, but not all glucagon-expressing cells coexpress Brn4, suggesting that Brn4 may be a marker of $\alpha$-cell progenitors (Heller et al., 2004). Perinatally, Brn4 expression is maintained in all $\alpha$-cells and sometimes in PP-cells (Heller et al., 2004).

Brn4 is dispensable for $\alpha$-cell identity, but sufficient for glucagon expression. In absence of Brn4, commitment and differentiation of $\alpha$-cells during development are not affected (Heller, 2004). However, Brn4 overexpression in $\beta$-cell lines is sufficient to induce glucagon expression.

\section{Specification of the exocrine lineage}

During pancreas development, by E14.5, cells budding from the tips of ductal branches commit into the acinar fate (Fig. 3D). From E16.5, these cells become polarized and begin storing zymogen granules, which contain digestive enzymes. Acinar cells become arranged into acini and are fully mature shortly after birth.

Terminally differentiated acinar cells have a highly developed rough endoplasmic reticulum producing a large amount of digestive enzymes. These are packed within zymogen granules, which are stored in the apical pole of the cells. Upon stimulation, exocytosis of zymogen granules is initiated, releasing their content into the lumen of the acinus. Exocytosis is regulated by acetylcholine, which is secreted by the autonomous nervous system, and during food ingestion and transit, by enteric hormones from the stomach (gastrin) and the duodenum (secretin and cholecystokinin). Exocrine secretion is coordinated between acinar cells through the activity of gap junctions, which are formed by hexameric complexes of acinar-specific connexins (connexin 26 and connexin 32).

The genetic program directing the specification and differentiation of exocrine progenitors remains elusive (Fig. 4). The establishment of the exocrine mass depends on the number of $P d \times 1+$ progenitor cells, and on Pdx1 levels from E13.5 (Stanger et al., 2007). Two transcription factors, Ptf1a, Mist1, are required to determine the exocrine fate, but are not sufficient. Wnt/ $\beta$-catenin and Notch signaling pathways participate in the expansion and differentiation of exocrine progenitors. In the adult, maintenance of the acinar cell mass relies on the activity of protective genes such as Srf. More specifically, Hnf6 is required for the ductal lineage.

\section{$P d x 1$}

$P d x 1$ activity is specifically required for the exocrine lineage from E13.5 (Holland et al., 2002). Upon $P d x 1$ repression from $\mathrm{E} 13.5$, the exocrine tissue is reduced and composed of immature cells. The defective ductal cells maintain Glut2 expression, and immature acinar cells fail to express Ptf1a, altering the normal expression of acinar markers, such as Cpa 1 and Amylase. Pdx1 expression is thus required for Ptf1ainduction, for early pancreas morphogenesis and, from E13.5, for the commitment and maturation of the exocrine compartment.

\section{Ptf1a (p48)}

Ptf1a / p48 is required for the transcription of acinar specific genes, such as elastase 1, $\alpha$-Amylase2and Chymotrypsinogen $B$ (Cockell et al., 1989). In absence of Ptf1a, these genes are still expressed but less efficiently, demonstrating that Ptf1a is necessary, but not sufficient, to drive exocrine specific gene expression (Cockell et al., 1995).

\section{Mist1}

The bHLHL transcription factor Mist 1 is specifically expressed in the lineage of serous secretory cells of the pancreas, the parotid 
and submandibular salivary. During pancreas development, Mist1 expression begins at E10.5 in a subset of primitive foregut cells. From E13 and throughout life, Mist1 is expressed in developing and mature acinar cells (Pin et al., 2001).

The role of Mist1 was investigated in Mist1-/- mice or by overexpressing a dominant negative form of Mist1 (Mist ${ }^{\text {MB }}$ ) in acinar cells (Pin et al., 2001, Zhu, 2004). The disruption of Mist1 does not alter the prenatal development of the pancreas. However, adult Mist1-/-and Mist ${ }^{M B}$ pancreata present a disorganization of acini, with a normal endocrine compartment. The acini are composed of poorly differentiated acinar cells, with few abnormal and misplaced zymogen granules, and displaying signs of stress such as cytoplasmic vacuolization and nuclear dysplasia (Pin et al., 2001). In Mist1-/- acinar cells, the exocytosis machinery is defective (Pin et al., 2001). The cholecystokinin (CKK) signaling pathway, which mediates the regulated secretion of zymogen granules, is altered. In addition, the expression of Connexin 32 is lost, thus hampering acinar gap junction formation (Rukstalis et al., 2003). The impaired maturation of acinar cells is associated with intracellular activation of the proenzyme carboxypeptidase A1 (Pin et al., 2001). Indeed, with aging, mutant pancreata have features of chronic pancreatitis, namely fibrosis, necrosis, metaplastic ducts and bleeding. These results indicate that Mist1 is required for the terminal differentiation of acinar cells, ensuring their functional stability and their maintenance in the adult.

\section{Wnt/ $\beta$-catenin signaling}

$W n t / \beta$-catenin signaling is required for the expansion and differentiation of the acinar lineage. Wnt/ $\beta$-catenin players are expressed in the developing pancreas from E12.5. Cytoplasmic $\beta$-catenin is present in all cells of E11.5-E13.5 pancreatic epithelia, and declines between E15.5-E17.5 to finally disappear at birth.

Since $\beta$-catenin-deficient mice die around E6.5, conditional genetic approaches were used to define the spatial and temporal requirement of this signaling pathway in pancreas development. The disruption of Wnt/ $\beta$-catenin obtained by the inactivation of $\beta$ catenin, or by overexpressing a dominant negative form of Frz8in $\mathrm{Pdx} 1^{+}$progenitors, leads to the selective hypoplasia of the postnatal exocrine pancreas (Murtaugh et al., 2005, Papadopoulou and Edlund, 2005). This reduction is due to reduced proliferation, concomitant with $c-M y c$ downregulation (Murtaugh et al., 2005). In absence of Wnt/ $\beta$-catenin signaling, the acinar differentiation is impaired from E16.5 (Wells et al., 2007). Like in adult Mist1 -/mutants, the few and dysfunctional acinar cells degenerate and lead to tissue remodelling by the age of two months (Pin et al., 2001, Wells et al., 2007).

The stabilization of $\beta$-catenin or the inactivation of $A p c$ in $P d \times 1$ expressing progenitors leads to constitutively active $\beta$-catenin signaling. This results in pancreatomegaly due to specific enlargement of the postnatal exocrine pancreas (Heiser et al., 2006, Strom et al., 2007). The expanded acinar mass presents a $c-M y c$ dependent increased proliferation of mature acinar cells (Strom et al., 2007).

Strom et al. have determined the existence of a temporal control of $\beta$-catenin signaling in acinar cells (Strom et al., 2007).

TABLE 1

EXPRESSION PATTERN OF GENES INVOLVED IN PANCREAS DEVELOPMENT AND HOMEOSTASIS

\begin{tabular}{|c|c|c|c|c|c|}
\hline Gene & $\begin{array}{l}\text { Expressed } \\
\text { from }\end{array}$ & in & $\begin{array}{l}\text { Restricted } \\
\text { from }\end{array}$ & to & References \\
\hline Hnf6 & E9-E9.5 & Pdx1+ cells & E18 & acinar and ductal cells & Landry et al. 1997, Rausa et al. 1997 \\
\hline$H I x b 9$ & E8 & two pancreatic primordia & E10.5-E12.5 & $\beta$-cells & Harrison et al. 1999, Li et al. 1999 \\
\hline$|s| 1$ & E9-E9.5 & dorsal primordium & $20-25 s$ & endocrine and mesenchymal cells & Karlsson et al. 1990 \\
\hline Hex & E7 & ventral promordium & & & Bort et al. 2004, Martinez Barbera et al. 2000, Thomas et al. 1998 \\
\hline$P d x 1$ & E8.5 & two pancreatic primordia & E16.5 & $\beta$ - and some $\delta$-cells & Jacquemin et al. 2003, Ohlsson et al. 1993, Wright et al. 1989 \\
\hline Ptf1a & E9.5 & Pdx1+ cells & E16.5 & acinar progenitors and mature cells & Krapp et al. 1996, Obata et al. 2001 \\
\hline Sox9 & E9.5 & Pdx1+ cells & E15.5 & $\begin{array}{l}\text { subset of Pdx1+ cells and then to centroacinar and } \\
\text { few ductal cells in the adult }\end{array}$ & Seymour et al. 2007 \\
\hline Prox 1 & E9.5 & Pdx1+ cells & E13.5 & Ngn $3+$ cells and proliferating cells & Burke et al. 2002 \\
\hline Ngn3 & E8.5 & scattered cells & birth & hormone-negative islet cells & Gu et al. 2002 \\
\hline Insm1 & E10.5 & Ngn3+ cells & E18.5 & all endocrine cells & Gierl et al. 2006, Mellitzer et al. 2006 \\
\hline Nkx2.2 & E9.5 & two pancreatic primordia & E12.5 & $\begin{array}{l}\text { subset of } \mathrm{Ngn} 3+\text { cells and after birth to } \alpha-, \beta \text { - and PP- } \\
\text { cells }\end{array}$ & Schwitzgebel et al. 2000, Sussel et al. 1998 \\
\hline Nkx6.1 & E10.5 & two pancreatic primordia & E15.5 & Ngn $3+$ and then to the $\beta$-cells & Henseleit et al. 2005, Oster et al. 1998, Sander et al. 2000 \\
\hline Nkx6.2 & E10.5 & two pancreatic primordia & E15.5 & $\alpha$ - and acinar cells & Sander et al. 2000 \\
\hline Pax4 & E9.5 & two pancreatic primordia & E13.5 & $\mathrm{Ngn} 3+$ and from E18.5 then to the $\beta$ - and $\delta$-cells & Smith et al. 1999, Sosa-Pineda et al. 1997, Wang et al. 2004 \\
\hline $\operatorname{Arx}$ & E9.5 & two pancreatic primordia & E13.5 & $\mathrm{Ngn} 3+$ and from E18.5 then to the $\alpha$-cells & Collombat et al. 2003 \\
\hline Pax6 & E9 & scattered Pdx1+ cells & birth & all endocrine cells & St-Onge et al. 1997 \\
\hline MafB & $\begin{array}{l}\text { E10.5 } \\
\text { E12.5 }\end{array}$ & $\begin{array}{l}\text { glucagon+ cells } \\
\text { glucagon+ and insulin+ cells }\end{array}$ & birth & $\alpha$-cells & Artner et al. 2006, Nishimura et al. 2006 \\
\hline MafA & E10.5 & insulin+ cells & - & $\beta$-cells & Kataoka et al. 2004, Nishimura et al. 2006 \\
\hline $\begin{array}{l}\text { BETA2/ } \\
\text { NeuroD }\end{array}$ & E9.5 & scattered Pdx1+ cells & E14.5 & Ngn $3+$ cells and then after birth to the $\beta$-cells & Itkin-Ansari et al. 2005, Naya et al. 1997 \\
\hline Brn4 & E10.5 & glucagon+ cells & E19 & glucagon+ and rare $\mathrm{PP}+$ cells & Heller et al. 2004 \\
\hline Mist1 & E10.5 & $\begin{array}{l}\text { scattered cells of the foregut } \\
\text { wall }\end{array}$ & E13 & acinar progenitors and mature cells & Pin et al. 2001 \\
\hline
\end{tabular}

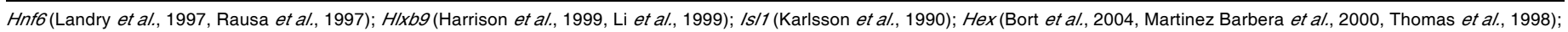

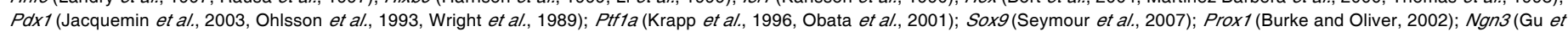

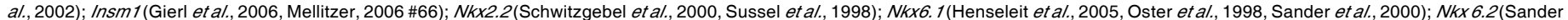

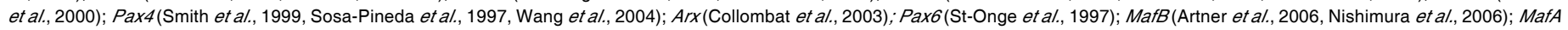
(Kataoka et al., 2004, Nishimura et al., 2006); BETA2/NeuroD (Itkin-Ansari et al., 2005, Naya et al., 1997); Brn4 (Heller et al., 2004); Mist1 (Pin et al., 2001). 
In the absence of $A p c$ from E10.5, there is an upregulation of $c$ Mycassociated with acinar cell hyperproliferation from birth to six months of age. This suggests that the sensitivity to $\beta$-catenin is restricted to mature acinar cells during a window of competence, after which $c-M y c$ is downregulated. This explains the lack of tumorigenesis in the pancreas after the loss of Apc (Strom et al., 2007), contrary to what happens in other organs with the very same Apc mutation.

\section{Notch signaling}

Adequate Notch signaling is absolutely required for exocrine pancreas commitment and differentiation.

Alteration of Notch signaling in $\mathrm{Pdx}^{+}$progenitors by overexpressing the intracellular domain of Notch 1 receptor $\left(N 1^{\prime C D}\right)$ or Notch3 repressor $\left(N 3^{C D}\right)$, hampers the formation of the pancreatic buds, such that only poorly ramified evaginations form. In these mutants, no Mist1-expressing acinar progenitors or amylase-positive cells appear.

\section{TGF $\beta$ signaling}

Appropriate TGF $\beta$ signaling is required for the renewal of acinar cells. The ubiquitous expression of Activin $\beta E$ subunit results in pancreas hypoplasia from two weeks of age (Hashimoto et al., 2006). In these mice, mature acinar cells progressively disappear due to insufficient proliferation, being replaced by adipose tissue. Intriguingly, the reverse experiment, i.e. the disruption of TGF $\beta$ signaling by expressing a dominant-negative mutant type // TGF $\beta$ receptor in acinar cells, also leads to postnatal pancreas hypoplasia: from 5 months of age, acinar cells have increased apoptosis and decreased proliferation. Like in chronic pancreatitis, there is ductal metaplasia and fibrosis, and acini are progressively replaced by adipose tissue (Bottinger et al., 1997).

\section{Srf}

Srf is also required for the postnatal maintenance of acinar cells. The MCM1-agamous-deficient serum response factor, Srf, is a transcription factor ubiquitously. Srf is involved in many cellular mechanisms, such as cell growth, differentiation and prevention of apoptosis. In the pancreas, broad Srf expression starts from E11 in the pancreatic epithelium, and persists during development and in the adult.

The conditional inactivation of $S r f$ in $\mathrm{Pdx} 1^{+}$cells alters pancreas development. After birth, Srf-/-mice have severely reduced acinar cell proliferation rates. From 6 weeks of age, mutant pancreata further undergo acinar cell deficit and chronic pancreatitis (Miralles et al., 2006). At 4 months of age, almost all acinar cells are replaced by adipose tissue, which contains ductal and endocrine cells.

\section{Hnf6}

Hnf6 promotes the formation of $\mathrm{Pdx} 1^{+}$and $\mathrm{Ngn}^{+}$progenitors and plays a determinant role in the differentiation of ductal cells. Hnf6 is expressed from E13.5 in the ductal lineage and persists in mature cells (Pierreux et al., 2006). The inactivation of Hnf6 disrupts ductal morphogenesis and leads to disorganization of the ductal network, with the formation of cysts (Pierreux et al., 2006). This ductal epithelium has dysmorphic traits: primary cilia are absent, Mucin and Hnf1 $\beta$ are not homogeneously induced, and there is persistence of G/ut2and $P d x 1$ expression (Jacquemin et al., 2000, Pierreux et al., 2006).

\section{Conclusion and perspectives}

The identification of key regulators of pancreatic development has progressed very rapidly in recent years. Understanding their role in commitment, progenitor cell expansion and differentiation represents an important challenge that should help devising new treatments for diabetes, pancreatitis or pancreatic cancer. For instance, such knowledge could be used to promote tissular maintenance or regeneration by blocking inappropriate cell death or survival, or by stimulating differentiation of newly formed cells or expansion of newly differentiated cells.

\section{References}

AFELIK, S., CHEN, Y. and PIELER, T. (2006). Combined ectopic expression of $\mathrm{Pdx} 1$ and $\mathrm{Ptf} 1 \mathrm{a} / \mathrm{p} 48$ results in the stable conversion of posterior endoderm into endocrine and exocrine pancreatic tissue. Genes Dev20: 1441-6.

AHLGREN, U., PFAFF, S.L., JESSELL, T.M., EDLUND, T. and EDLUND, $\mathrm{H}$. (1997). Independent requirement for ISL1 in formation of pancreatic mesenchyme and islet cells. Nature 385: 257-60.

APELQVIST, A., LI, H., SOMMER, L., BEATUS, P., ANDERSON, D.J., HONJO, T., HRABE DE ANGELIS, M., LENDAHL, U. and EDLUND, H. (1999). Notch signalling controls pancreatic cell differentiation. Nature 400: 877-81.

ARTNER, I., LE LAY, J., HANG, Y., ELGHAZI, L., SCHISLER, J.C., HENDERSON, E., SOSA-PINEDA, B. and STEIN, R. (2006). MafB: an activator of the glucagon gene expressed in developing islet alpha- and beta-cells. Diabetes55: 297-304.

ASHERY-PADAN, R., ZHOU, X., MARQUARDT, T., HERRERA, P., TOUBE, L., BERRY, A. and GRUSS, P. (2004). Conditional inactivation of Pax6 in the pancreas causes early onset of diabetes. Dev Bio/269: 479-88.

BORT, R., MARTINEZ-BARBERA, J.P., BEDDINGTON, R.S. and ZARET, K.S. (2004). Hex homeobox gene-dependent tissue positioning is required for organogenesis of the ventral pancreas. Development 131: 797-806.

BOTTINGER, E.P., JAKUBCZAK, J.L., ROBERTS, I.S., MUMY, M., HEMMATI, P., BAGNALL, K., MERLINO, G. and WAKEFIELD, L.M. (1997). Expression of a dominant-negative mutant TGF-beta type II receptor in transgenic mice reveals essential roles for TGF-beta in regulation of growth and differentiation in the exocrine pancreas. EMBO J16: 2621-33.

BURKE, Z. and OLIVER, G. (2002). Prox1 is an early specific marker for the developing liver and pancreas in the mammalian foregut endoderm. Mech Dev 118: 147-55.

COCKELL, M., STEVENSON, B.J., STRUBIN, M., HAGENBUCHLE, O. and WELLAUER, P.K. (1989). Identification of a cell-specific DNA-binding activity that interacts with a transcriptional activator of genes expressed in the acinar pancreas. Mol Cell Bio/9: 2464-76.

COCKELL, M., STOLARCZYK, D., FRUTIGER, S., HUGHES, G.J., HAGENBUCHLE, O. and WELLAUER, P.K. (1995). Binding sites for hepatocyte nuclear factor 3 beta or 3 gamma and pancreas transcription factor 1 are required for efficient expression of the gene encoding pancreatic alpha-amylase. Mol Cell Biol 15: 1933-41.

COLLOMBAT, P., HECKSHER-SORENSEN, J., BROCCOLI, V., KRULL, J., PONTE, I., MUNDIGER, T., SMITH, J., GRUSS, P., SERUP, P. and MANSOURI, A. (2005). The simultaneous loss of Arx and Pax4 genes promotes a somatostatinproducing cell fate specification at the expense of the alpha- and beta-cell lineages in the mouse endocrine pancreas. Development 132: 2969-80.

COLLOMBAT, P., MANSOURI, A., HECKSHER-SORENSEN, J., SERUP, P., KRULL, J., GRADWOHL, G. and GRUSS, P. (2003). Opposing actions of Arx and Pax4 in endocrine pancreas development. Genes Dev 17: 2591-603.

DEUTSCH, G., JUNG, J., ZHENG, M., LORA, J. and ZARET, K.S. (2001). A bipotential precursor population for pancreas and liver within the embryonic endoderm. Development 128: 871-81.

FUJITANI, Y., FUJITANI, S., BOYER, D.F., GANNON, M., KAWAGUCHI, Y., RAY, 
M., SHIOTA, M., STEIN, R.W., MAGNUSON, M.A. and WRIGHT, C.V. (2006). Targeted deletion of a cis-regulatory region reveals differential gene dosage requirements for $\mathrm{Pdx} 1$ in foregut organ differentiation and pancreas formation. Genes Dev20: 253-66.

GIERL, M.S., KAROULIAS, N., WENDE, H., STREHLE, M. and BIRCHMEIER, C. (2006). The zinc-finger factor Insm1 (IA-1) is essential for the development of pancreatic beta cells and intestinal endocrine cells. Genes Dev20: 2465-78.

GRADWOHL, G., DIERICH, A., LEMEUR, M. and GUILLEMOT, F. (2000). neurogenin 3 is required for the development of the four endocrine cell lineages of the pancreas. Proc Nat/ Acad Sci USA 97: 1607-11.

GRAPIN-BOTTON, A., MAJITHIA, A.R. and MELTON, D.A. (2001). Key events of pancreas formation are triggered in gut endoderm by ectopic expression of pancreatic regulatory genes. Genes Dev 15: 444-54.

GU, G., DUBAUSKAITE, J. and MELTON, D.A. (2002). Direct evidence for the pancreatic lineage: NGN3+ cells are islet progenitors and are distinct from duct progenitors. Development 129: 2447-57.

HALE, M.A., KAGAMI, H., SHI, L., HOLLAND, A.M., ELSASSER, H.P., HAMMER, R.E. and MACDONALD, R.J. (2005). The homeodomain protein PDX1 is required at mid-pancreatic development for the formation of the exocrine pancreas. Dev Bio/286: 225-37.

HARMON, E.B., APELQVIST, A.A., SMART, N.G., GU, X., OSBORNE, D.H. and KIM, S.K. (2004). GDF11 modulates NGN3+ islet progenitor cell number and promotes beta-cell differentiation in pancreas development. Development 131: 6163-74.

HARRISON, K.A., THALER, J., PFAFF, S.L., GU, H. and KEHRL, J.H. (1999). Pancreas dorsal lobe agenesis and abnormal islets of Langerhans in Hlxb9deficient mice. Nat Genet 23: 71-5.

HASHIMOTO, O., USHIRO, Y., SEKIYAMA, K., YAMAGUCHI, O., YOSHIOKA, K., MUTOH, K. and HASEGAWA, Y. (2006). Impaired growth of pancreatic exocrine cells in transgenic mice expressing human activin betaE subunit. Biochem Biophys Res Commun 341: 416-24.

HEBROK, M., KIM, S.K. and MELTON, D.A. (1998). Notochord repression of endodermal Sonic hedgehog permits pancreas development. Genes Dev 12: 1705-13.

HEISER, P.W., LAU, J., TAKETO, M.M., HERRERA, P.L. and HEBROK, M. (2006). Stabilization of beta-catenin impacts pancreas growth. Development 133: 2023-32.

HELLER, R.S., STOFFERS, D.A., LIU, A., SCHEDL, A., CRENSHAW, E.B., 3RD, MADSEN, O.D. and SERUP, P. (2004). The role of Brn4/Pou3f4 and Pax6 in forming the pancreatic glucagon cell identity. Dev Bio/268: 123-34.

HENSELEIT, K.D., NELSON, S.B., KUHLBRODT, K., HENNINGS, J.C., ERICSON, $\mathrm{J}$. and SANDER, M. (2005). NKX6 transcription factor activity is required for alpha- and beta-cell development in the pancreas. Development 132: 3139-49.

HERRERA, P.L. (2000). Adult insulin- and glucagon-producing cells differentiate from two independent cell lineages. Development 127: 2317-22.

HOLLAND, A.M., GONEZ, L.J., NASELLI, G., MACDONALD, R.J. and HARRISON, L.C. (2005). Conditional expression demonstrates the role of the homeodomain transcription factor $\mathrm{Pdx} 1$ in maintenance and regeneration of beta-cells in the adult pancreas. Diabetes 54: 2586-95.

HOLLAND, A.M., HALE, M.A., KAGAMI, H., HAMMER, R.E. and MACDONALD, R.J. (2002). Experimental control of pancreatic development and maintenance. Proc Nat/ Acad Sci USA 99: 12236-41.

ITKIN-ANSARI, P., MARCORA, E., GERON, I., TYRBERG, B., DEMETERCO, C., HAO, E., PADILLA, C., RATINEAU, C., LEITER, A., LEE, J.E. et al. (2005). NeuroD1 in the endocrine pancreas: localization and dual function as an activator and repressor. Dev Dyn 233: 946-53.

JACQUEMIN, P., DURVIAUX, S.M., JENSEN, J., GODFRAIND, C., GRADWOHL, G., GUILLEMOT, F., MADSEN, O.D., CARMELIET, P., DEWERCHIN, M., COLLEN, D. et al. (2000). Transcription factor hepatocyte nuclear factor 6 regulates pancreatic endocrine cell differentiation and controls expression of the proendocrine gene Ngn3. Mol Cell Bio/20: 4445-54.

JACQUEMIN, P., LEMAIGRE, F.P. and ROUSSEAU, G.G. (2003). The Onecut transcription factor HNF-6 (OC-1) is required for timely specification of the pancreas and acts upstream of $\mathrm{Pdx}-1$ in the specification cascade. Dev Bio/258: 105-16.

JACQUEMIN, P., YOSHITOMI, H., KASHIMA, Y., ROUSSEAU, G.G., LEMAIGRE,
F.P. and ZARET, K.S. (2006). An endothelial-mesenchymal relay pathway regulates early phases of pancreas development. Dev Bio/290: 189-99.

JENSEN, J., PEDERSEN, E.E., GALANTE, P., HALD, J., HELLER, R.S., ISHIBASHI, M., KAGEYAMA, R., GUILLEMOT, F., SERUP, P. and MADSEN, O.D. (2000). Control of endodermal endocrine development by Hes-1. Nat Genet24: 36-44

JOHANSSON, K.A., DURSUN, U., JORDAN, N., GU, G., BEERMANN, F., GRADWOHL, G. and GRAPIN-BOTTON, A. (2007). Temporal control of neurogenin 3 activity in pancreas progenitors reveals competence windows for the generation of different endocrine cell types. Dev Cel/12: 457-65.

JONSSON, J., CARLSSON, L., EDLUND, T. and EDLUND, H. (1994). Insulinpromoter-factor 1 is required for pancreas development in mice. Nature 371 : 606-9.

KARLSSON, O., THOR, S., NORBERG, T., OHLSSON, H. and EDLUND, T. (1990) Insulin gene enhancer binding protein Isl-1 is a member of a novel class of proteins containing both a homeo- and a Cys-His domain. Nature 344: 879-82.

KATAOKA, K., SHIODA, S., ANDO, K., SAKAGAMI, K., HANDA, H. and YASUDA K. (2004). Differentially expressed Maf family transcription factors, c-Maf and MafA, activate glucagon and insulin gene expression in pancreatic islet alphaand beta-cells. J Mol Endocrino/32: 9-20.

KAWAGUCHI, Y., COOPER, B., GANNON, M., RAY, M., MACDONALD, R.J. and WRIGHT, C.V. (2002). The role of the transcriptional regulator Ptf1a in converting intestinal to pancreatic progenitors. Nat Genet 32: 128-34.

KIM, S.K., HEBROK, M. and MELTON, D.A. (1997). Notochord to endoderm signaling is required for pancreas development. Development 124: 4243-52.

KIM, S.K. and MELTON, D.A. (1998). Pancreas development is promoted by cyclopamine, a hedgehog signaling inhibitor. Proc Natl Acad Sci USA 95: 13036-41.

KRAPP, A., KNOFLER, M., FRUTIGER, S., HUGHES, G.J., HAGENBUCHLE, O. and WELLAUER, P.K. (1996). The p48 DNA-binding subunit of transcription factor PTF1 is a new exocrine pancreas-specific basic helix-loop-helix protein. EMBO J15: 4317-29.

LAMMERT, E., CLEAVER, O. and MELTON, D. (2001). Induction of pancreatic differentiation by signals from blood vessels. Science 294: 564-7.

LANDRY, C., CLOTMAN, F., HIOKI, T., ODA, H., PICARD, J.J., LEMAIGRE, F.P. and ROUSSEAU, G.G. (1997). HNF-6 is expressed in endoderm derivatives and nervous system of the mouse embryo and participates to the crossregulatory network of liver-enriched transcription factors. Dev Bio/192: 247-57.

LI, H., ARBER, S., JESSELL, T.M. and EDLUND, H. (1999). Selective agenesis of the dorsal pancreas in mice lacking homeobox gene Hlxb9. Nat Genet 23: 6770.

LI, H. and EDLUND, H. (2001). Persistent expression of Hlxb9 in the pancreatic epithelium impairs pancreatic development. Dev Bio/240: 247-53.

MARTINEZ BARBERA, J.P., CLEMENTS, M., THOMAS, P., RODRIGUEZ, T., MELOY, D., KIOUSSIS, D. and BEDDINGTON, R.S. (2000). The homeobox gene $\mathrm{Hex}$ is required in definitive endodermal tissues for normal forebrain, liver and thyroid formation. Development 127: 2433-45.

MELLITZER, G., BONNE, S., LUCO, R.F., VAN DE CASTEELE, M., LENNESAMUEL, N., COLLOMBAT, P., MANSOURI, A., LEE, J., LAN, M., PIPELEERS, D. et al. (2006). IA1 is NGN3-dependent and essential for differentiation of the endocrine pancreas. EMBO J25: 1344-52.

MIRALLES, F., LAMOTTE, L., COUTON, D. and JOSHI, R.L. (2006). Interplay between FGF10 and Notch signalling is required for the self-renewal of pancreatic progenitors. Int J Dev Bio/50: 17-26.

MURTAUGH, L.C., LAW, A.C., DOR, Y. and MELTON, D.A. (2005). Beta-catenin is essential for pancreatic acinar but not islet development. Development 132: 4663-74.

NAYA, F.J., HUANG, H.P., QIU, Y., MUTOH, H., DEMAYO, F.J., LEITER, A.B. and TSAI, M.J. (1997). Diabetes, defective pancreatic morphogenesis, and abnormal enteroendocrine differentiation in BETA2/NeuroD-deficient mice. Genes Dev11: 2323-34.

NEVE, B., FERNANDEZ-ZAPICO, M.E., ASHKENAZI-KATALAN, V., DINA, C., HAMID, Y.H., JOLY, E., VAILLANT, E., BENMEZROUA, Y., DURAND, E., BAKAHER, N. et al. (2005). Role of transcription factor KLF11 and its diabetesassociated gene variants in pancreatic beta cell function. Proc Nat/ Acad SCi USA 102: 4807-12.

NISHIMURA, W., KONDO, T., SALAMEH, T., EL KHATTABI, I., DODGE, R. 
BONNER-WEIR, S. and SHARMA, A. (2006). A switch from MafB to MafA expression accompanies differentiation to pancreatic beta-cells. Dev Bio/293: 526-39.

OBATA, J., YANO, M., MIMURA, H., GOTO, T., NAKAYAMA, R., MIBU, Y., OKA, C. and KAWAICHI, M. (2001). p48 subunit of mouse PTF1 binds to RBPJkappa/CBF-1, the intracellular mediator of Notch signalling, and is expressed in the neural tube of early stage embryos. Genes Cells 6: 345-60.

OHLSSON, H., KARLSSON, K. and EDLUND, T. (1993). IPF1, a homeodomaincontaining transactivator of the insulin gene. EMBO J12: 4251-9.

OSTER, A., JENSEN, J., EDLUND, H. and LARSSON, L.I. (1998). Homeobox gene product Nkx 6.1 immunoreactivity in nuclei of endocrine cells of rat and mouse stomach. $J$ Histochem Cytochem 46: 717-21.

PAPADOPOULOU, S. and EDLUND, H. (2005). Attenuated Wnt signaling perturbs pancreatic growth but not pancreatic function. Diabetes 54: 2844-51.

PIERREUX, C.E., POLL, A.V., KEMP, C.R., ClOTMAN, F., MAESTRO, M.A., CORDI, S., FERRER, J., LEYNS, L., ROUSSEAU, G.G. and LEMAIGRE, F.P. (2006). The transcription factor hepatocyte nuclear factor-6 controls the development of pancreatic ducts in the mouse. Gastroenterology 130: 532-41.

PIN, C.L., RUKSTALIS, J.M., JOHNSON, C. and KONIECZNY, S.F. (2001). The bHLH transcription factor Mist1 is required to maintain exocrine pancreas cell organization and acinar cell identity. J Cell Bio/155: 519-30.

RAUSA, F., SAMADANI, U., YE, H., LIM, L., FLETCHER, C.F., JENKINS, N.A., COPELAND, N.G. and COSTA, R.H. (1997). The cut-homeodomain transcriptional activator HNF-6 is coexpressed with its target gene HNF-3 beta in the developing murine liver and pancreas. Dev Bio/192: 228-46.

RUKSTALIS, J.M., KOWALIK, A., ZHU, L., LIDINGTON, D., PIN, C.L. and KONIECZNY, S.F. (2003). Exocrine specific expression of Connexin32 is dependent on the basic helix-loop-helix transcription factor Mist1. JCel/Sci116: 3315-25.

SANDER, M., SUSSEL, L., CONNERS, J., SCHEEL, D., KALAMARAS, J., DELA CRUZ, F., SCHWITZGEBEL, V., HAYES-JORDAN, A. and GERMAN, M. (2000). Homeobox gene Nkx6.1 lies downstream of Nkx2.2 in the major pathway of beta-cell formation in the pancreas. Development 127: 5533-40.

SANVITO, F., HERRERA, P.L., HUARTE, J., NICHOLS, A., MONTESANO, R., ORCI, L. and VASSALLI, J.D. (1994). TGF-beta 1 influences the relative development of the exocrine and endocrine pancreas in vitro. Development 120: 3451-62.

SCHWITZGEBEL, V.M., SCHEEL, D.W., CONNERS, J.R., KALAMARAS, J., LEE, J.E., ANDERSON, D.J., SUSSEL, L., JOHNSON, J.D. and GERMAN, M.S. (2000). Expression of neurogenin3 reveals an islet cell precursor population in the pancreas. Development 127: 3533-42.

SERUP, P., PETERSEN, H.V., PEDERSEN, E.E., EDLUND, H., LEONARD, J., PETERSEN, J.S., LARSSON, L.I. and MADSEN, O.D. (1995). The homeodomain protein IPF-1/STF-1 is expressed in a subset of islet cells and promotes rat insulin 1 gene expression dependent on an intact E1 helix-loop-helix factor binding site. Biochem J310 (Pt 3): 997-1003.

SEYMOUR, P.A., FREUDE, K.K., TRAN, M.N., MAYES, E.E., JENSEN, J., KIST, R., SCHERER, G. and SANDER, M. (2007). SOX9 is required for maintenance of the pancreatic progenitor cell pool. Proc Nat/ Acad Sci USA 104: 1865-70.

SHALABY, F., ROSSANT, J., YAMAGUCHI, T.P., GERTSENSTEIN, M., WU, X.F., BREITMAN, M.L. and SCHUH, A.C. (1995). Failure of blood-island formation and vasculogenesis in Flk-1-deficient mice. Nature 376: 62-6.

SMART, N.G., APELQVIST, A.A., GU, X., HARMON, E.B., TOPPER, J.N., MACDONALD, R.J. and KIM, S.K. (2006). Conditional expression of Smad7 in pancreatic beta cells disrupts TGF-beta signaling and induces reversible diabetes mellitus. PLOS Bio/4: e39.

SMITH, S.B., EE, H.C., CONNERS, J.R. and GERMAN, M.S. (1999). Pairedhomeodomain transcription factor PAX4 acts as a transcriptional repressor in early pancreatic development. Mol Ce/l Bio/ 19: 8272-80.

SORIANO, P. (1999). Generalized lacZ expression with the ROSA26 Cre reporter strain. Nat Genet 21: 70-1.

SOSA-PINEDA, B. (2004). The gene Pax4 is an essential regulator of pancreatic beta-cell development. Mol Cells 18: 289-94.

SOSA-PINEDA, B., CHOWDHURY, K., TORRES, M., OLIVER, G. and GRUSS, P. (1997). The Pax4 gene is essential for differentiation of insulin-producing beta cells in the mammalian pancreas. Nature 386: 399-402.

ST-ONGE, L., SOSA-PINEDA, B., CHOWDHURY, K., MANSOURI, A. and GRUSS, $P$. (1997). Pax6 is required for differentiation of glucagon-producing alpha-cells in mouse pancreas. Nature 387: 406-9.

STANGER, B.Z., TANAKA, A.J. and MELTON, D.A. (2007). Organ size is limited by the number of embryonic progenitor cells in the pancreas but not the liver. Nature 445: 886-91.

STOFFERS, D.A., ZINKIN, N.T., STANOJEVIC, V., CLARKE, W.L. and HABENER, J.F. (1997). Pancreatic agenesis attributable to a single nucleotide deletion in the human IPF1 gene coding sequence. Nat Genet 15: 106-10.

STROM, A., BONAL, C., ASHERY-PADAN, R., HASHIMOTO, N., CAMPOS, M.L., TRUMPP, A., NODA, T., KIDO, Y., REAL, F.X., THOREL, F. et al. (2007). Unique mechanisms of growth regulation and tumor suppression upon Apc inactivation in the pancreas. Development 134: 2719-25.

SUSSEL, L., KALAMARAS, J., HARTIGAN-O'CONNOR, D.J., MENESES, J.J., PEDERSEN, R.A., RUBENSTEIN, J.L. and GERMAN, M.S. (1998). Mice lacking the homeodomain transcription factor $\mathrm{Nkx2.2}$ have diabetes due to arrested differentiation of pancreatic beta cells. Development 125: 2213-21.

THOMAS, M.K., LEE, J.H., RASTALSKY, N. and HABENER, J.F. (2001). Hedgehog signaling regulation of homeodomain protein islet duodenum homeobox-1 expression in pancreatic beta-cells. Endocrinology 142: 1033-40.

THOMAS, M.K., RASTALSKY, N., LEE, J.H. and HABENER, J.F. (2000). Hedgehog signaling regulation of insulin production by pancreatic beta-cells. Diabetes 49: 2039-47.

THOMAS, P.Q., BROWN, A. and BEDDINGTON, R.S. (1998). Hex: a homeobox gene revealing peri-implantation asymmetry in the mouse embryo and an early transient marker of endothelial cell precursors. Development 125: 85-94.

WANG, J., ELGHAZI, L., PARKER, S.E., KIZILOCAK, H., ASANO, M., SUSSEL, L. and SOSA-PINEDA, B. (2004). The concerted activities of Pax4 and Nkx2.2 are essential to initiate pancreatic beta-cell differentiation. Dev Bio/266: 178-89.

WANG, J., KILIC, G., AYDIN, M., BURKE, Z., OLIVER, G. and SOSA-PINEDA, B. (2005). Prox1 activity controls pancreas morphogenesis and participates in the production of «secondary transition» pancreatic endocrine cells. Dev Bio/286: 182-94.

WELLS, J.M., ESNI, F., BOIVIN, G.P., ARONOW, B.J., STUART, W., COMBS, C., SKLENKA, A., LEACH, S.D. and LOWY, A.M. (2007). Wnt/beta-catenin signaling is required for development of the exocrine pancreas. BMC Dev Biol 7: 4.

WRIGHT, C.V., SCHNEGELSBERG, P. and DE ROBERTIS, E.M. (1989). XIHbox 8: a novel Xenopus homeo protein restricted to a narrow band of endoderm. Development 105: 787-94.

ZHANG, C., MORIGUCHI, T., KAJIHARA, M., ESAKI, R., HARADA, A., SHIMOHATA, H., OISHI, H., HAMADA, M., MORITO, N., HASEGAWA, K. et al. (2005). MafA is a key regulator of glucose-stimulated insulin secretion. Mo/Ce// Bio/25: 496976. 


\section{Further Related Reading, published previously in the Int. J. Dev. Biol.}

See our Special Issue Fertilization in honor of David Garbers and edited by P.M. Wassarman and V.D. Vacquier at: http://www.ijdb.ehu.es/web/contents.php?vol=52\&issue=5/6

See our Special Issue Evolution \& Development edited by Jaume Baguna and Jordi García-Fernández at: http://www.intjdevbiol.com/web/contents. php?vol=47\&issue=7-8 2006 ISI **Impact Factor $=3.577^{* *}$

Interplay between FGF10 and Notch signalling is required for the selfrenewal of pancreatic progenitors

Francisco Miralles, Luciane Lamotte, Dominique Couton and Rajiv L. Joshi Int. J. Dev. Biol. (2006) 50: 17-26

Sox9, a novel pancreatic marker in Xenopus.

Young-Hoon Lee and Jean-Pierre Saint-Jeannet

Int. J. Dev. Biol. (2003) 47: 459-462

Defining the cell lineages of the islets of Langerhans using transgenic mice.

Pedro L Herrera

Int. J. Dev. Biol. (2002) 46: 97-103

Role of cell division in branching morphogenesis and differentiation of the embryonic pancreas.

L D Horb and J M Slack

Int. J. Dev. Biol. (2000) 44: 791-796

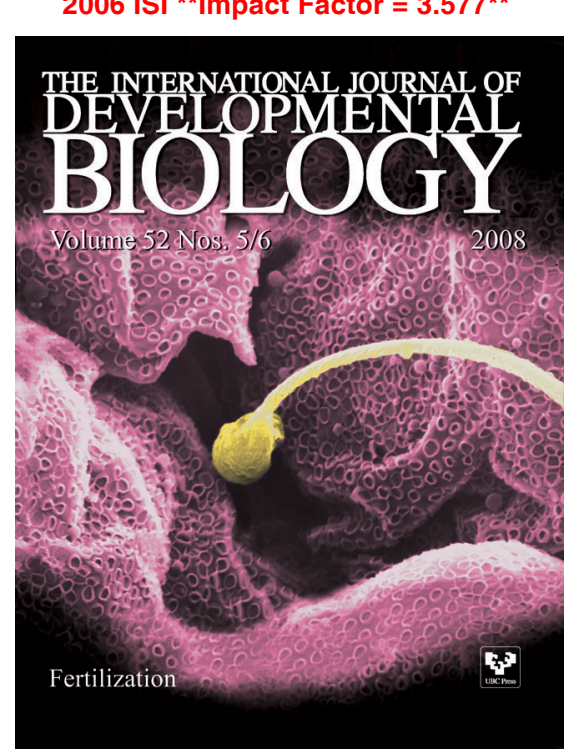

